\title{
Inhibition of ovulation by tyrosine kinase inhibitors in the in vitro perfused rat ovary
}

\author{
M. Matousek, M. Mikuni, K. Mitsube, M. Yoshida and M. Brännström \\ Department of Obstetrics and Gynaecology, Göteborg University, Göteborg, Sweden
}

\begin{abstract}
Protein tyrosine kinase activity, leading to tyrosine phosphorylation of the intracellular domains of receptors or non-receptor proteins, is an important feature of downstream signalling after receptor binding of a variety factors, such as growth factors and cytokines. Since several members of these classes of paracrine-autocrine mediator may be involved in the intraovarian events of ovulation, the present study was designed to evaluate the effect of protein tyrosine kinase inhibition on the in vitro perfused rat ovary. Immature rats were primed with $20 \mathrm{iu}$ pregnant mares' serum gonadotrophin $48 \mathrm{~h}$ before surgical isolation of the right ovary with connecting vasculature. The ovary was placed in a perfusion system for either $10 \mathrm{~h}$, to examine ovarian concentrations of the etablished ovulatory mediators plasminogen activator, prostaglandins $E_{2}$ and $F_{2 \alpha^{\prime}}$ or for $20 \mathrm{~h}$, enabling a complete ovulatory process to occur in vitro. Ovulation was induced by ovine $\mathrm{LH}\left(0.2 \mu \mathrm{g} \mathrm{ml}^{-1}\right)$ in the presence of the phosphodiesterase inhibitor 3-isobutyl-1methylxanthine $\left(0.2 \mathrm{mmol} \mathrm{l}^{-1}\right)$ and the effects of two different protein tyrosine kinase inhibitors, genistein and tyrphostin A25, were studied. Unstimulated control ovaries did not ovulate and showed low secretion of progesterone and oestradiol. Addition of $\mathrm{LH}+3$-isobutyl-1-methylxanthine resulted in a marked stimulation of steroid release, and ovulations occurred in all ovaries $(9.0 \pm 0.9$; mean \pm SEM). The protein tyrosine kinase inhibitors, genistein and tyrphostin A25, significantly inhibited ovulation at the higher concentrations tested $\left(3.0 \pm 0.3\right.$ at $100 \mu$ mol genistein ${ }^{-1} ; 5.8 \pm 1.0$ at $500 \mu \mathrm{mol}$ tyrphostin A25 $\mathrm{l}^{-1}$ ) but no effect was seen at lower concentrations. The presence of genistein and tyrphostin A25 at any concentration used did not significantly decrease the $\mathrm{LH}+3$-isobutyl-1-methylxanthine-induced progesterone or oestradiol concentrations. The intraovarian concentrations of plasminogen activator activity, and prostaglandin $E_{2}$

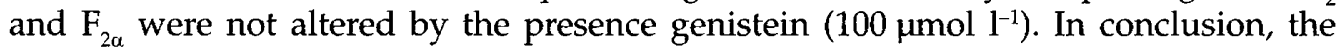
results of the present study indicate that protein tyrosine kinase signalling pathways are integral parts of the mammalian ovulatory process but do not involve actions on the synthesis of steroids, plasminogen activator or prostaglandins.
\end{abstract}

\section{Introduction}

Mammalian ovulation involves complex intraovarian mechanisms that are regulated by a number of autocrine and paracrine factors (Brännström et al., 1996). Binding of LH to its receptor induces the expression of several genes or activates enzyme systems to increase the intrafollicular concentrations of mediators which, in a redundant fashion, control the continued ovulatory process. The LH-induced signal to cause ovulation seems to be transduced primarily by the CAMP-protein kinase A (Brännström et al., 1987a) and phosphoinositol-protein kinase C (Kaufmann et al., 1992) second messenger systems. Several mediators of the growth factor and cytokine families may be of importance in the cascade leading to oocyte meiosis, follicle rupture and

Revised manuscript received 27 January 1999. luteinization. Several of these mediators are dependent on tyrosine phosphorylation. Among these mediators, epidermal growth factor (EGF) seems to be involved in the stimulation of oocyte meiosis and cumulus cell expansion (Downs, 1989). Inhibitory effects of EGF on the ovulatory mechanism may also exist, since administration of EGF to the in vitro perfused rabbit ovary results in a significant reduction in ovulatory efficiency (Endo et al., 1992). EGF possesses intrinsic protein tyrosine kinase (PTK) activity (Smith et al., 1993) and there are several PTK interaction sites on the intracellular domain of the EGF receptor (Seedorf, 1995). Platelet-derived growth factor (PDGF) enhances plasminogen activator (PA) activity in granulosa cells but not in theca cells of the ovulating follicle in domestic hens (Tilly and Johnson, 1990). Another factor of this family, vascular epidermal growth factor (VEGF), may be involved in control of angiogenesis and permeability changes at ovulation (Koos, 1993). 
Inflammatory changes are active in ovulation and several of these processes may be controlled by cytokines (Brännström et al., 1993a, 1994), such as interleukin (IL) 1, IL6 and granulocyte macrophage colony stimulating factor (GM-CSF). The expression of IL-1 in rat theca interstitial cells is induced by LH (Hurwitz et al., 1991), and IL-1 induces ovulation in vitro (Brännström et al., 1993b). Furthermore, a regulatory effect of colony stimulating factor 1 (CSF-1) on rate of ovulation has been indicated (Cohen et al., 1997). The intracellular signalling pathways for these cytokines are reported to involve activity of non-receptor PTK (Tadagatsu, 1995), which would lead to enhanced downstream signal transductions (Schaffhausen, 1995).

The aim of the present study was to investigate the possible role of PTK in the mechanism controlling the ovulatory process by use of genistein, which is a potent noncompetitive inhibitor (Akiyama and Ogawara, 1991) of soluble and membrane-bound PTK (Tadagatsu, 1995). Genistein is an isoflavone phyto-oestrogen that has both oestrogenic and anti-oestrogenic effects (Wähäle et al., 1995), as well as other non-specific effects (Grunicke, 1991). In view of these non-PTK related effects by genistein, a second PTK inhibitor (tyrphostin A25) was also used. A well characterized method involving isolated rat ovaries during in vitro perfusion (Brännström, 1993a) was used to exclude systemic effects of PTK inhibition on the ovulatory process.

\section{Materials and Methods}

\section{Chemicals and hormones}

Ovine luteinizing hormone (NIADDK-oLH-26) was kindly provided by the NIADDK and National Hormone and Pituitary Program (Rockville, MD). Pregnant mares' serum gonadotrophin (PMSG), genistein, tyrphostin A25 and 3isobutyl-1-methylxanthine (IBMX) were obtained from Sigma Chemical Company (St Louis, MO); ketamine was obtained from Park Davis (Barcelona); xylazine was obtained from Bayer (Leverkusen); medium M199 was obtained from GIBCO (Geithersburg, MD); gentamycin sulphate was obtained from Biological Industries (Kibbutz Beit Haemek); bovine serum albumin (BSA; fraction V) was obtained from Boehringer Mannheim (Mannheim); insulin was obtained from Novo (Bagsvaerd) and heparin was obtained from Lövens (Ballerup).

\section{Animals and surgical procedure}

Sprague-Dawley rats (Beekey, Stockholm) were housed under controlled conditions with light on from 05:00 to 19:00 $\mathrm{h}$ and fed water and food ad libitum. At 09:00 $\mathrm{h}$ on day 28 of age, the rats were injected s.c. with 20 iu PMSG. This treatment induces follicular growth, and follicles of the preovulatory stage acquired $48 \mathrm{~h}$ later. On the morning of day 30 of age, the rats were anaesthetized with ketamine: xylazine (67:13 $\mathrm{mg} \mathrm{kg}^{-1}$ bodyweight) i.p. and were then given $300 \mathrm{iu}$ heparin i.v. through a femoral vein. The operation procedure is described in detail by Koos et al. (1984). Briefly, a laparotomy was performed and the caudal abdominal parts of the aorta and the vena cava were cannulated in a retrograde direction. All the connecting vessels, except the right ovarian vein and artery, were ligated and severed. At this stage, $2-5 \mathrm{ml}$ saline was injected through the aorta cannule to flush the blood from the ovarian tissue. At the end of the surgical procedure, the aorta and the vena cava were ligated and cut cranially to the level of renal vessels and caudally to cannulation. The bursa was gently opened before the placement of the ovary in the perfusion chamber to enable ovulated oocytes to sediment to the bottom of a beaker, which was placed inside the perfusion chamber.

\section{Perfusion}

The procedure and experimental set up is shown schematically (Fig. 1). The perfusions were performed as described by Koos et al. (1984) with minor modifications (Brännström et al., 1987b). The perfusion pressure was maintained at $80 \mathrm{mmHg}$ and resulted in an average flow of

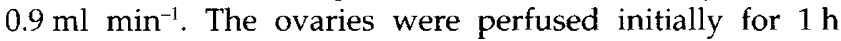
before any agents were added, to allow metabolic stabilization of the tissue. Only ovarian preparations exhibiting flow rates between 0.7 and $1.3 \mathrm{ml} \mathrm{min}^{-1}$ at 80 $\mathrm{mmHg}$ perfusion pressure were used to exclude specimens with vascular leakage or clotted vascular beds. The perfusion medium was $30 \mathrm{ml}$ M199 with Earl's salts supplemented with insulin $\left(0.02 \mathrm{iu} \mathrm{ml}^{-1}\right)$, gentamycin sulphate $\left(50 \mu \mathrm{m} \mathrm{ml}^{-1}\right)$, $4 \% \mathrm{BSA}$ and $0.026 \mathrm{~mol}$ sodium bicarbonate $\mathrm{l}^{-1}$. A pH of 7.4 was maintained when the perfusion medium was continuously gassed with $5 \% \mathrm{CO}_{2}$ and $95 \% \mathrm{O}_{2}$. Genistein and tyrphostin A25 were diluted in 1\% (v/v) DMSO as stock solutions. Aliquot volumes $(1 \mathrm{ml})$ of the stock solutions were added to the perfusion medium $30 \mathrm{~min}$ before $\mathrm{LH}(0.2 \mu \mathrm{g}$ $\left.\mathrm{ml}^{-1}\right)$ and IBMX $\left(0.2 \mathrm{mmol} \mathrm{l}^{-1}\right)$ administration to get final concentrations of 10 or $100 \mu \mathrm{mol}$ genistein $\mathrm{l}^{-1}$ and 100 or 500 $\mu$ mol tyrphostin A25 $\mathrm{l}^{-1}$. Maximum volume $(1 \mathrm{ml})$ of diluent was added to unstimulated and LH + IBMX control perfusions. Four to six ovaries were perfused simultaneously in identical perfusion systems. Samples $(1 \mathrm{ml})$ of perfusion medium were withdrawn at different time points throughout the perfusion period and stored at $-70^{\circ} \mathrm{C}$ for later analysis. The same volume of fresh medium was added to the perfusion medium after each sampling, to keep a constant volume in the system. One set of ovaries was perfused for $20 \mathrm{~h}$ to study ovulation rate and steroidogenesis.

Another set of ovaries was perfused for $10 \mathrm{~h}$ to study the concentrations of the ovulatory mediators of prostaglandin (PG) $E_{2}, P_{2 u}$ and PA activity after LH + IBMX and 100 $\mu$ mol genistein $\mathrm{l}^{-1}$. After perfusion, each ovary was divided into two sections and snap frozen to $-70^{\circ} \mathrm{C}$ until evaluation.

\section{Ovulation rate}

Oocytes were collected from the bottom of the beaker inserted in the perfusion chamber after $20 \mathrm{~h}$ perfusion. The number of ovulated oocytes was counted under a stereomicroscope, with the observer unaware of the experimental data. 


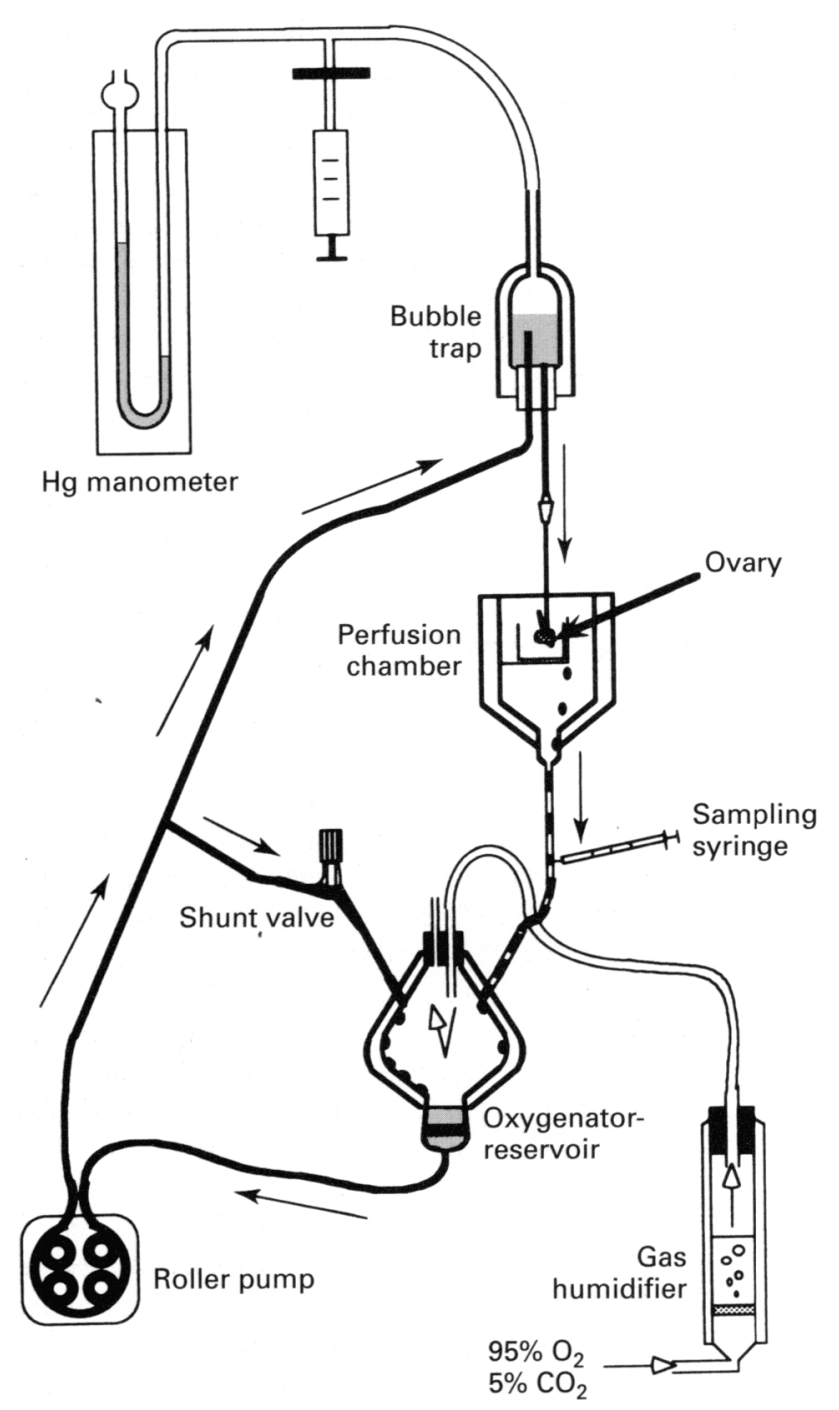

Fig. 1. Schematic figure of the perfusion apparatus. The ovary is contained in the perfusion chamber. Perfusion medium is circulated as indicated by the arrows. Oxygenation takes place when the medium is passing down along the inside of the oxygenation reservoir. Pressure is monitored by the $\mathrm{Hg}$ manometer.

\section{Steroid assay}

Samples were kept frozen $\left(-70^{\circ} \mathrm{C}\right)$ until analysis. Progesterone and oestradiol concentrations in samples of perfusion medium were analysed by radioimmunoassay technique using specific antisera purchased from ImmunoChemicals (Tumba). The validity controls have been described by Hillensjö et al. (1984). The standard curves were calculated from eight standards (6.25-800 pg per tube) using a logit-log transformation.

\section{$P G E_{y}, P G F_{2 \alpha}$ and PA assay}

The ovarian tissue perfused for $10 \mathrm{~h}$ was homogenized (glass-glass homogenizer; 5000 r.p.m. $30 \mathrm{~s}$ ) in $1 \mathrm{ml}$ buffer (0.1 mol acetate buffer $\mathrm{l}^{-1}$ at $\mathrm{pH} 4.5$ for $\mathrm{PGE}_{2}$ and $\mathrm{PGF}_{2 \alpha}$

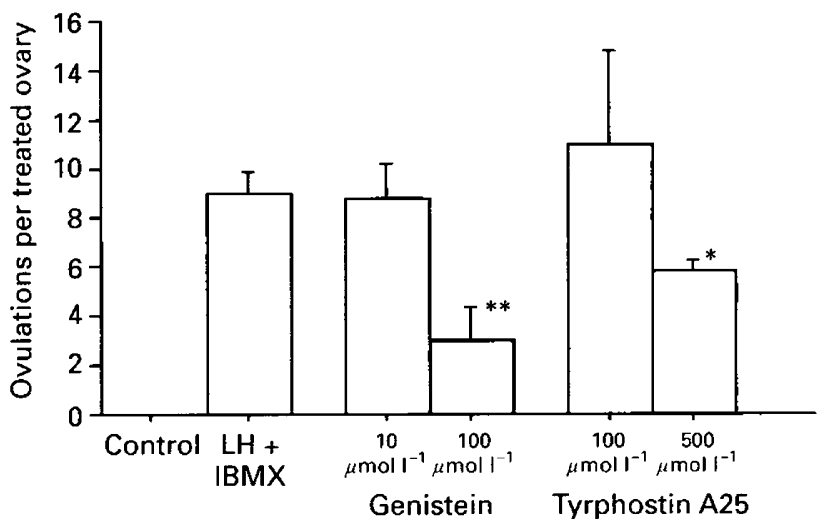

Fig. 2. Effects of genistein and tyrphostin A25 on ovulation rate in the in vitro perfused rat ovary. Asterisks indicate values significantly lower than those of the $\mathrm{LH}+3$-isobutyl-1-methylxanthine (IBMX) group $\left({ }^{*} P<0.05 ;{ }^{* *} P<0.01\right)$.

assays, and $0.05 \mathrm{~mol}$ Tris buffer $\mathrm{l}^{-1}$ at $\mathrm{pH} 8.0$ for PA assay). After centrifugation at $10000 \mathrm{~g}$ for $20 \mathrm{~min}$, the supernatants were transferred to propylene tubes and $\mathrm{PGE}_{2}$ and $\mathrm{PGF}_{2 \alpha}$ concentrations were analysed by enzyme immunoassay kit (RPN222; TRK900 Amersham, Bucks).

The procedure for PA activity assay was essentially as described for ovarian PA activity evaluation (Espey et al., 1985).

\section{Statistical analysis}

The results are presented as the mean \pm SEM. Statistical differences regarding ovulation rate and steroid concentrations at each time point were calculated by the Kruskal-Wallis test followed by the Mann-Whitney U test. A value of $P<0.05$ was considered significant for individual comparisons.

\section{Results}

\section{Ovulation rate}

The number of ovulations for the different experimental groups are shown (Fig. 2). In the unstimulated control group $(n=6)$, no ovulation occurred, whereas addition of $\mathrm{LH}+$ IBMX $(n=8)$ resulted in ovulations from all perfused ovaries $(9.0 \pm 0.9 ;$ mean \pm SEM $)$. Administration of $10 \mu \mathrm{mol}$ genistein $\mathrm{l}^{-1}(n=6)$ did not significantly change the LH + IBMXinduced ovulation rate $(8.8 \pm 1.3)$. The ovulation rate was significantly reduced $(P<0.01)$ by the administration of a tenfold higher concentration of genistein $(3.0 \pm 0.3 ; n=5)$ and the higher concentration of tyrphostin A25 (5.8 \pm 1.0 at $\left.500 \mu \mathrm{moll}{ }^{-1} ; n=4\right)$.

\section{Steroid concentrations}

The concentrations of progesterone and oestradiol in the perfusion medium, evaluated at five different time points throughout the perfusions are presented (Figs 3 and 4). 


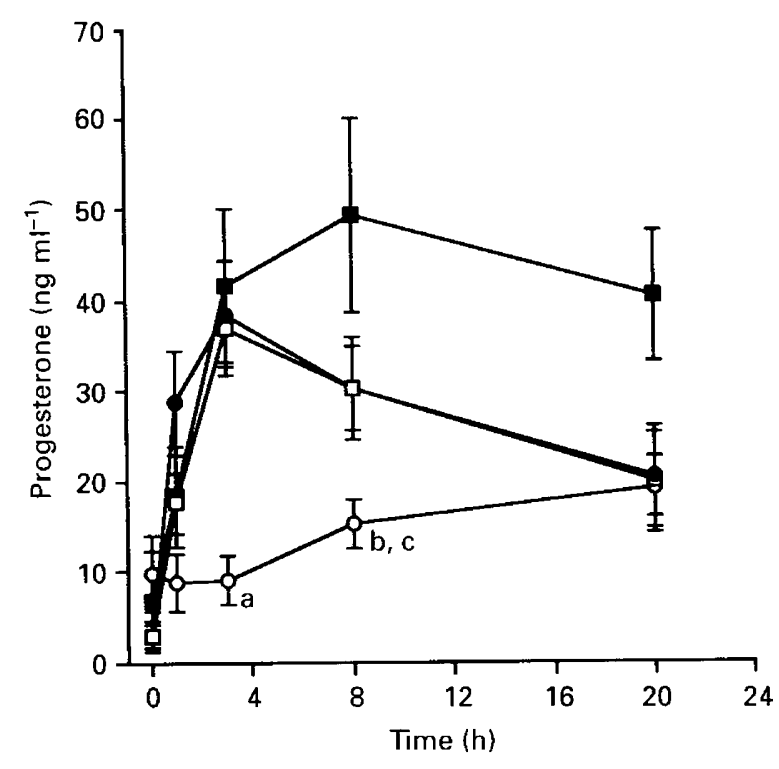

Fig. 3. Progesterone concentrations in the medium used to perfuse rat ovaries in vitro. Each symbol represents the mean of values ( \pm SEM) at each time point during perfusion. Significantly lower concentrations of progesterone were detected in the unstimulated control group compared with those of the other groups at 3 and $8 \mathrm{~h}$ (a: significantly lower $(P<0.01)$ than all other groups; b: lower than the $10 \mu \mathrm{mol}$ genistein $\mathrm{l}^{-1}$ group $(P<0.05)$; $\mathrm{c}$ : lower than the $100 \mu \mathrm{mol}$ genistein $1^{-1}$ group $\left.(P<0.01)\right)$. There were no differences among the three treatment groups at any time point. $\mathrm{O}$ : control; $\mathbf{O}: \mathbf{L H}+3-$ isobutyl-1-methylxanthine (IBMX); $\square: \quad \mathrm{LH}+\mathrm{IBMX}+10 \mu \mathrm{mol}$ genistein $\mathrm{l}^{-1} ; \mathbf{D}: \mathrm{LH}+\mathrm{IBMX}+100 \mu \mathrm{mol}$ genistein $\mathrm{l}^{-1}$.

Unstimulated control ovaries showed lower secretion of progesterone and oestradiol than the LH + IBMX-stimulated groups, with significantly lower concentrations of progesterone at $3 \mathrm{~h}$ than in all other groups and, at $8 \mathrm{~h}$, than in the genistein-treated groups (Fig. 3). Oestradiol concentrations in the control group were significantly lower than they were in the $\mathrm{LH}+$ IBMX group at 1,3 and $8 \mathrm{~h}$ (Fig. 4). The presence of genistein or tyrphostin A25 (data not shown) did not significantly change the progesterone or oestradiol concentrations compared with those in the LH + IBMX groups at any time point (Figs 3 and 4).

\section{Intraovarian concentrations of $P A, P G E_{2}$ and $P G F_{20}$}

The concentrations of PA activity in the ovary after $10 \mathrm{~h}$ of perfusion with $\mathrm{LH}+\mathrm{IBMX}$ were $2.43 \pm 0.38 \mathrm{iu} \mathrm{mg}^{-1}$ wet ovarian mass. Genistein exposure did not significantly $(P>0.05)$ alter the concentrations of PA activity $(3.60 \pm 0.74)$. The concentrations of $\mathrm{PGE}_{2}$ and $\mathrm{PGF}_{2 \alpha}$ were $1.13 \pm 0.08$ and $0.33 \pm 0.02$, respectively. These concentrations were not significantly $(P>0.05)$ altered by genistein treatment $(1.08 \pm$ 0.32 and $0.25 \pm 0.05 \mathrm{ng} \mathrm{mg}^{-1}$ wet ovarian mass, respectively).

\section{Discussion}

The ovulatory process bears many similarities to an inflammatory reaction (Espey, 1980) and among many

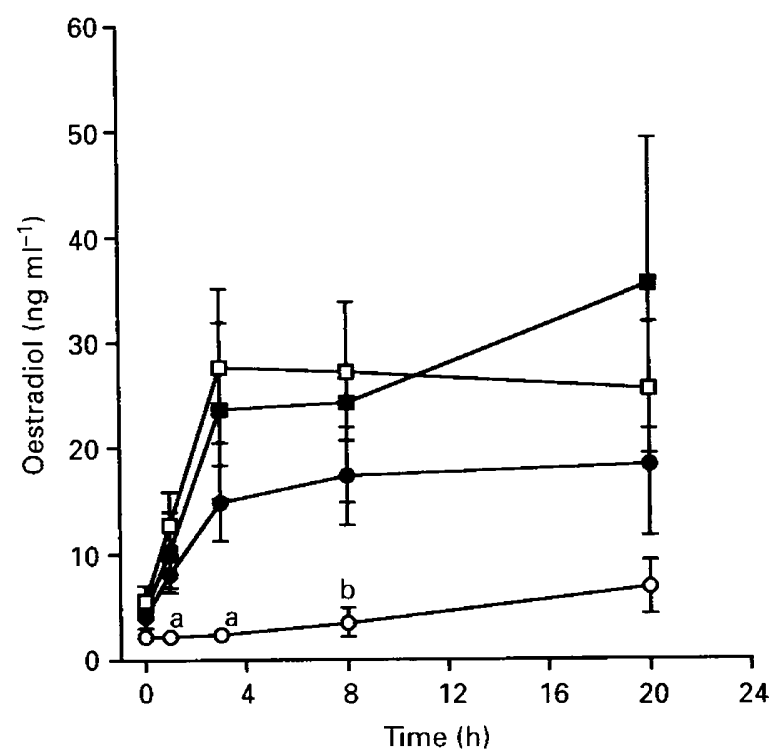

Fig. 4. Oestradiol concentrations in the medium used to perfuse rat ovaries in vitro. Each symbol represents the mean values ( \pm SEM) at each time point during perfusion. Significantly lower concentrations of oestradiol were detected in the unstimulated group compared with those in the $\mathrm{LH}+3$-isobutyl-1-methylxanthine (IBMX) group and $10 \mu \mathrm{mol}$ genistein $\mathrm{l}^{-1}$ group (a: significantly lower than LH + IBMX + $10 \mu \mathrm{mol}$ genistein $\mathrm{l}^{-1}$ group $(P<0.01-0.05)$; b: significantly lower than $\mathrm{LH}+\mathrm{IBMX}$ group and the $10 \mu \mathrm{mol}$ genistein $\mathrm{l}^{-1}$ group $\left.(P<0.05)\right)$. There were no significant differences among the three treatment groups at any time point. $O$ : control; $: \mathrm{LH}+\mathrm{IBMX} ; \square: \mathrm{LH}+\mathrm{IBMX}+$ $10 \mu \mathrm{mol}$ genistein $\mathrm{l}^{-1} ; \mathbf{D}: \mathrm{LH}+\mathrm{IBMX}+100 \mu \mathrm{mol}$ genistein $\mathrm{l}^{-1}$.

mediators of inflammation, several of the recently discovered cytokines may actively regulate ovulation by inducing intrafollicular production of ovulation-associated mediators, such as progesterone (Brännström et al., 1993a), collagenase (Hurwitz et al., 1993), prostaglandins (Kokia et al, 1992) and nitric oxide (Ben-Shlomo et al., 1994). While it was first recognized that growth factors were likely to be involved mostly in early stages of follicular development, it is now accepted that several members of this family of substances also regulate ovarian and follicular functions at the preovulatory stage (Koos, 1993; Mulherin and Schomberg, 1993). Several of the cytokines and growth factors involved in intraovarian regulation use either receptor or intracellular non-receptor tyrosine kinase pathways for their intracellular signalling.

The present study demonstrates for the first time that the PTK pathway is involved in the intraovarian regulation of mammalian ovulation. The presence in the perfusion medium of either of two structurally different PTK inhibitors at the concentrations of 100 and $500 \mu \mathrm{mol} \mathrm{l}^{-1}$, respectively, significantly reduced the LH-induced ovulatory response. This inhibition of ovulation did not seem to affect the PA or prostaglandin systems.

The concentrations at which these PTK inhibitors inhibited ovulation are relatively high. However, other studies also performed in vitro on tissue from the female genital tract, revealed inhibitory effects of genistein at similar concentrations. In isolated myometrial tissue from pregnant 
rats, genistein decreased the L-type calcium current and the half-maximal inhibition of voltage-dependent concentration was obtained at $50 \mu \mathrm{mol} \mathrm{l}^{-1}$ (Kusaka and Sperelakis, 1995). In nonreproductive tissue, such as vascular smooth muscle tissue, a dose-dependent inhibition of contraction was seen, with maximum inhibition obtained at $100 \mu \mathrm{mol}$ genistein $\mathrm{I}^{-1}$ (Filipeanu et al., 1995). The effective inhibition of PTK activity at a concentration of about $100 \mu \mathrm{mol} \mathrm{l}^{-1}$ was demonstrated by monitoring the phosphorylation of the EGF receptor in a cell line in the presence of various concentrations of genistein (Akiyama and Ogawara, 1991). Tyrphostin A25 inhibits PTK over a similar or slightly higher concentration range to genistein, as has been demonstrated in aortic endothelial cells (Yano et al., 1996).

Although the half-maximal effects of both genistein and tyrphostin A25 seem to be similar, the present study showed that genistein effectively inhibited ovulation at $100 \mathrm{mmol} \mathrm{l}^{-1}$, whereas tyrphostin A25 was ineffective at this concentration. The relatively high concentrations of both PTK inhibitors added to obtain inhibition of ovulation in this specific perfusion system are in accordance with earlier studies in which, in some cases, drugs needed to be present in the micromolar range (Brännström, 1993b). The reason for this dependence of relatively high concentrations could be adsorption of compounds to the tubing material and the fact that the perfused ovary represents an intact organ, to which the compounds have to be transported by diffusion from the vascular bed to the target cells. A difference in these two factors between the two compounds may explain why fivefold higher concentrations of tyrphostin A25 had to be used. Nevertheless, the fact that PTK inhibitors had no negative effects on steroid release, prostaglandin concentrations and PA activity indicates that their effects on ovulation were not the result of non-specific cytotoxicity.

The presence of genistein or tyrphostin A25 at either concentration examined in the present study did not significantly change the LH + IBMX-stimulated steroid release. Earlier studies in rats indicated that the preovulatory production of oestradiol was of no importance for ovulation (Morioka et al., 1988) but that progesterone was essential (Brännström and Janson, 1988). The fact that steroid output was not negatively affected by genistein or tyrphostin A25 treatment indicates that the PTK pathway is not directly involved in steroid regulation in the rat pre-ovulatory follicle and that the ovulation-inhibiting effect of PTK inhibitor is not related to the inhibition of progesterone synthesis. In previous experiments, another tyrosine kinase inhibitor, tyrphostin AG18, has been shown to inhibit the FSH-induced gene expression of the three key steroidogenic enzymes, cholesterol side-chain cleavage cytochrome $450,3 \beta$ hydroxysteroid dehydrogenase, and aromatase cytochrome 450 , in rat granulosa cells in a differentiation stage before the preovulatory stage (Orly et al., 1994). The inhibition of these steroidogenic enzymes by PTK inhibitors was shown to be less pronounced in granulosa cells of the preovulatory stage and in luteinized granulosa cells (Orly et al., 1996). However, the oestradiol and progesterone concentration profiles in this recirculated perfusion media were similar, with an initial sharp increase up to $4 \mathrm{~h}$ and then a plateau. These profiles indicate a selective and marked decrease in oestrogen synthesis after $4 \mathrm{~h}$ of the ovulatory process, which is in line with conditions in vivo where the blood concentrations of oestradiol decrease $4-6 \mathrm{~h}$ after the LH surge (Goff and Henderson 1979). Oestradiol is not adsorbed to the walls of this perfusion system and constant concentrations in the media indicate that ovarian secretion is minimal (Bruning et al., 1981). In contrast, progesterone is rapidly adsorbed, with a $t_{\frac{1}{2}}$ of $2.9 \mathrm{~h}$ of exogenously added progesterone (Brännström et al., 1987b). In the present study, progesterone concentrations in the $100 \mu \mathrm{mol}$ genistein $1^{-1}$ group did not decrease at the same rate as in the other LH + IBMXstimulated groups. However, there was no significant difference in progesterone concentration among these groups at any time point.

In the present study, the intraovarian concentrations of $\mathrm{PGE}_{2}$ and $\mathrm{PGF}_{2 \alpha}$ were measured when maximal. Prostaglandins have been implicated as important mediators in the process of follicular rupture, since inhibitors of prostaglandin synthesis depress the ovulatory rate in vivo in several species, including humans (Killich and Elstein, 1987). The intraovarian role of prostaglandins in this process was substantiated by the detection of an LH-induced increase in the intrafollicular prostaglandin concentration (LeMaire et al., 1975) and the finding that prostaglandin synthesis blockers inhibit follicular rupture in the isolated in vitro perfused ovary (Hamada et al., 1977; Sogn et al., 1987). Since a PTK inhibitor has been shown to block both LH- and GnRHmediated induction of cyclooxygenase 2 in cultured granulosa cells (Morris and Richards, 1993), it was assumed that at least part of the inhibitory action on ovulation of the PTK inhibitors in the present study was due to decreased prostaglandin production. However, the unchanged prostaglandin concentrations within the ovary observed in the present study indicate another mechanism for the PTK inhibition of ovulation.

Plasminogen activators, especially tissue type PA (tPA) appear to play an important role in the ovulatory process (Beers et al., 1975). Plasminogen activator is secreted from the granulosa cells and the PA gene activity is enhanced around the time of the LH surge (Shimamoto et al., 1993), and growth factors, such as EGF, have been implicated as regulators of PA expression (Galway et al., 1989). In the present study, the $10 \mathrm{~h}$ perfusion showed no significant difference in intraovarian PA concentration when the gonadotrophinstimulated ovaries and those also treated with genistein were compared. These findings indicate that the PTK pathways in the ovulatory process do not involve the PA system.

Exogenously added EGF decreases ovulatory efficiency in the in vitro perfused rabbit ovary (Endo et al., 1992). This finding is somewhat in contrast to those of the present study, in which a presumed inhibition of EGF-mediated effects by PTK inhibition also resulted in a decreased ovulatory response. This discrepancy may be explained by reported species differences between the rabbit and rat in the regulation of ovulation (Brännström and Janson, 1988) or by an EGF-mediated negative regulation of the ovulatory process in rats that was not detected in the present study, in which it is likely that several important PTK mediated pathways were inhibited.

In conclusion, this study demonstrates that PTK is 
involved critically in the intraovarian events of follicular rupture but does not influence the luteinization process in terms of progesterone secretion. The action of PTK does not involve the prostaglandin or PA systems.

The authors would like to thank the National Hormone and Pituitary Program of the NIDDK for the generous gift of LH. The study was supported by grants from the Swedish Medical Research Council (11607 to MB), Medical Faculty of Göteborg University, Göteborg Medical Society and Hjalmar Svensson Research Foundation.

\section{References}

Akiyama T and Ogawara $\mathbf{H}$ (1991) Use and specifity of Genistein as inhibitor of protein tyrosine kinases Methods in Enzymology 201 362-370

Beers WH, Strickland S and Reich E (1975) Ovarian plasminogen activator: relationship to ovulation and hormonal regulation Cell 6379-386

Ben-Shlomo I, Kokia E, Adashi EY and Payne DW (1994) Interleukin 1 beta stimulates nitrite production in the rat ovary. Evidence to heterologous cell-cell interaction and for insulin-mediated regulation of the inducible isoform of nitric oxide synthase Biology of Reproduction 51 310-318

Brännström M (1993a) In vitro perfused ovary. In Methods in Reproductive Toxicology pp 160-169 Eds C Chopin and JJ Heidell. Academic Press, New York

Brännström M (1993b) Inhibitory effects of mifepristone (RU 486) on ovulation in the isolated perfused rat ovary Contraception 48 393-402

Brännström M and Janson PO (1988) Progesterone is a mediator in the ovulatory process of the in vitro perfused rat ovary Biology of Reproduction $\mathbf{4 0}$ 1170-1178

Brännström M, Koos RD, Le Maire WJ and Janson PO (1987a) Cyclic adenosine $3^{\prime}, 5^{\prime}$-monophosphate-induced ovulation in the perfused rat ovary and its mediation by prostaglandins Biology of Reproduction 37 1047-1053

Brännström M, Johansson BM, Sogn J and Janson PO (1987b) Characterisation of an in vitro perfused rat ovary model: ovulation rate, oocyte maturation, steroidogenesis and influence of PMSG priming Acta Physiologica Scandinavica 130 107-114

Brännström M, Wang L and Norman RG (1993a) Effects of cytokines on prostaglandin production and steroidogenesis of incubated preovulatory follicles in the rat Biology of Reproduction 48 165-171

Brännström M, Wang L and Norman R (1993b) Ovulatory effects of interleukin $1 \beta$ on the perfused rat ovary Endocrinology 132 399-404

Brännström M, Norman RJ, Seamark RF and Robertson S (1994) Rat ovary produces cytokines during ovulation Biology of Reproduction 50 88-94

Brännström M, Mikuni M and Peterson M (1996) Ovulation-associated intraovarian events. In The Ovary pp 113-123 Eds M Filicori and C Flamigni. Elsevier Science BV, Amsterdam

Bruning PF, Jonker KM and Boerema-Baan AW (1981) Adsorption of steroid hormones by plastic tubing Journal of Biochemistry 14 553-555

Cohen PE, Zhu L and Pollard JW (1997) Absence of colony stimulating factor 1 in osteopetrotic (csfmop/csfmop) mice disrupts estrous cycles and ovulation Biology of Reproduction 56 110-118

Downs SM (1989) Specificity of epidermal growth factor action on maturation of the oocyte and cumulus oophorus in vitro. Biology of Reproduction 41 371-379

Endo K, Atlas SJ, Rone JD, Zanagnolo VL, Kuo TC, Dharmarajan AM and Wallach EE (1992) Epidermal growth factor inhibits follicular response to human gonadotropin: possible role of cell to cell communication in the response to gonadotropin Endocrinology 130 186-192

Espey LL (1980) Ovulation as an inflammatory reaction - a hypothesis Biology of Reproduction 22 73-106

Espey L, Shimada H, Okamura H and Mori T (1985) Effects of various agents on ovarian plasminogen activator during ovulation in pregnant mares' serum gonadotropin-primed immature rats Biology of Reproduction 32 1087-1094

Filipeanu CM, Brailoiu E, Huhurez G, Slatineau S, Baltatu $O$ and Branisteanu D (1995) Multiple effects of tyrosine kinase inhibitors on vascular smooth muscle contractions European Journal of Pharmacology 281 29-35
Galway AB, Oikawa M, Ny T and Hsueh AJ (1989) Epidermal growth factor stimulates tissue plasminogen activator activity and messenger ribonucleic acid concentrations in cultured rat granulosa cells: mediations by pathways independent of protein kinases A and C Endocrinology 125 126-135

Goff AK and Henderson KM (1979) Changes in follicular fluid and serum concentration of steroids in PMS-treated immature rats following $\mathrm{LH}$ administration Biology of Reproduction $201153-1157$

Grunicke HH (1991) The cell membrane as a target for cancer chemotherapy European Journal of Cancer 27 281-284

Hamada Y, Bronson RA, Wright KH and Wallach EE (1977) Ovulation in the perfused rabbit ovary: influence of prostaglandins and prostaglandins inhibitors Biology of Reproduction 17 58-63

Hillensjö T, Ekholm C and Hedin L (1984) Effects of gonadotropin releasing hormone upon the pattern of steroidogenesis in isolated preovulatory rat follicles Acta Endocrinologica (Copenhagen) 105 105-111

Hurwitz A, Ricciarelli E, Botero L, Rohan RM, Hernandez ER and Adashi EY (1991) Endocrine- and autocrine-mediated regulation of rat ovarian (theca-interstitial) interleukin 1 gene expression: gonadotropin-dependent preovulatory acquisition Endocrinology 129 3427-3429

Hurwitz A, Dushnik M, Solomon H, Ben-Shirit A, Finci-Yeheskel Z, Milwidsky A, Meyer M, Adashi EY and Yagel S (1993) Cytokine-mediated regulation of the rat ovarian function. Interleukin 1 stimulates the accumulation of $92 \mathrm{kDa}$ gelatinase Endocrinology $1322709-2714$

Kaufman G, Dharmarajan AM, Takehara Y, Cropp CS and Wallach EE (1992) The role of protein kinase $C$ in gonadotropin-induced ovulation in the in vitro perfused rabbit ovary Endocrinology 131 1804-1809

Killich S and Elstein M (1987) Pharmacological production of luteinized unruptured follicles by prostaglandin synthase inhibitors Fertility and Sterility 47 773-777

Kokia E, Hurwitz Allmenn, Ricciarelli E, Tedeschi C, Resnick CE, Mitchell MD and Adashi EY (1992) Interleukin $1 \beta$ stimulates ovarian prostaglandin biosynthesis: evidence for heterologus contact-independent cell-cell interaction Endocrinology 130 3095-3097

Koos RD (1993) Ovarian angiogenesis. In The Ovary pp 433-453 Eds EY Adashi and PCK Leung. Raven Press, New York

Koos RD, Jaccarino FJ, Magaril RL and LeMaire WJ (1984) Perfusion of the rat ovary in vitro: methodology, induction of ovulation, and pattern of steroidogenesis Biology of Reproduction 30 1135-1141

Kusaka M and Sperelakis N (1995) Inhibition of L-type calcium current by genistein, a tyrosine kinase inhibitor, in pregnant rat myometrial cells Biochemica et Biophysica Acta 1240 196-200

LeMaire WJ, Lindner R and Marsh JM (1975) Pre- and postovulatory changes in the concentration of prostaglandins in rat Graafian follicle Prostaglandins 9221-229

Morioka N, Brännström M, Koos RD and LeMaire WJ (1988) Ovulation in the perfused ovary in vitro: further evidence that estrogen is not required Steroids 45 173-183

Morris JK and Richards JS (1993) Hormone induction of luteinization and prostaglandin endoperoxidase synthase 2 involves multiple cellular signaling pathways Endocrinology 133 770-778

Mulheron GW and Schomberg DW (1993) The intraovarian transforming growth factor system. In The Ovary 337-361 Eds EY Adashi and PCK Leung. Raven Press, New York

Orly J, Rey Z, Greenberg NM and Richards JS (1994) Tyrosine kinase inhibitor AG18 arrests FSH-induced granulosa cell differentiation: use of reverse transcriptase-polymerase chain reaction assay for multiple messenger ribonucleic acids Endocrinology 134 2236-2246

Orly, Clemens JW, Singer O and Richards JS (1996) Effects of hormones and protein kinase inhibitors on expression of steroidogenetic enzyme promotors in electroporated primary rat granulosa cells Biology of Reproduction 54 208-218

Seedorf K (1995) Intercellular signalling by growth factors Metabolism 44 24-32

Schaffhausen B (1995) SH2 domain structure and function Biochemica et Biophysica Acta 1242 61-75

Shimamoto T, Yamoto M and Nakano R (1993) Possible involvement of protein kinase $C$ in gonadotropin-induced ovulation in the rat ovary Endocrinology 133 2127-2132

Smith JA, Sharron H, Francis and Corbin JD (1993) Autophosphorylation: a salient feature of protein kinases Molecular and Cellular Biochemistry 127/128 $51-70$

Sogn JH, Curry TE, Brännström M, LeMaire WJ, Koos RD, Papkoff $H$ and Janson PO (1987) Inhibition of follicle-stimulating hormone-induced 
ovulation by indomethacin in perfused rat ovary Biology of Reproduction 36 536-542

Tadagatsu T (1995) Cytokine signalling through nonreceptor protein tyrosine kinases Science 268 251-255

Tilly JL and Johnson AL (1990) Effects of several growth factors on plasminogen activity in granulosa and theca cells of the domestic hen Poultry Science 69 292-299
Yano Y, Giebel J and Bauer ES (1996) Tyrosine phosphorylation of pp125 and paxillin in aortic endothelial cells induced by mechanical strain American Journal of Physiology 271 635-649

Wähälä K, Hase T and Adlercreutz H (1995) Synthesis and labelling of isoflavone phytoestogens, including daidzein and genistein Proceedings of the Society for Experimental Biology and Medicine 208 24-32 